\title{
In vitro Efficacy of Fungicides and Bioagents against Wilt of Pigeonpea Caused by Fusarium oxysporum f. sp. udum
}

\author{
Pradnya Khillare $^{1 *}$, Sunita J. Magar ${ }^{1}$ and H. N. Markad ${ }^{2}$ \\ ${ }^{1}$ Department of Plant Pathology, College of Agriculture, Latur, India \\ ${ }^{2}$ Department of Plant Pathology, MPKV, Rahuri, India \\ *Corresponding author
}

Keywords

Bioagents,

Fungicides,

Fusarium

oxysporum f. sp.

udum, Wilt of

pigeonpea

\section{Article Info}

Accepted:

15 August 2020

Available Online:

10 September 2020

\section{A B S T R A C T}

Pigeonpea wilt disease caused by Fusarium oxysporum f. sp. udum is one of most devasting seedborne disease. In this experiment total eight seed dressing fungicides at their recommended dosages were evaluated in-vitro by poisoned food technique, against Fusarium oxysporum f. sp. udum causing wilt. The systemic fungicides viz. Carbendazim 50\% WP, thiophanate methyl 70\% WP, tebuconazole 25\% WG, pyroclostrobin 20\% WG and combi fungicides viz. corboxin $37.5 \%+$ thiram $37.5 \%$ WP, carbendazim $12 \%+$ mancozeb 63\% $75 \mathrm{WP}$ and contact fungicides captan 75\% WP were evaluated. However, the fungicides viz., tebuconazole $25 \% \mathrm{WG}$, carboxin $37.5 \%$ + thiram $37.5 \% 75 \mathrm{WP}$ and carbendazim 12\% + mancozeb $63 \% 75$ WP were found most effective with 100 per cent mycelial growth inhibition of Fusariumoxysporumf. sp. udum. The eight bioagents evaluated by dual culture technique, among that most effective bioagent was Trichoderma harzianum, which resulted in significantly highest mycelial growth inhibition (85.62\%), followed by T. hamatum (82.61\%). T. asperellum, Aspergillus niger, T. koningii, T. longibrachitum which also caused mycelial growth inhibition in the range of 61.64 to 77.32 per cent.

\section{Introduction}

Pigeonpea (Cajanus cajan (L.) Millsp.) is a legume belonging to family of Fabaceae. Other common names are "Red gram, Arhar, Tur, Congo pea, Gunga pea, Turvarica, Thogari or Ganduland No-eye pea" (Sheela, 2013). It is an important grain legume crop of rainfed agriculture in the tropics and subtropics. Compared with other grain legumes, pigeonpea ranks only sixth in area and production, but it is used in more diverse ways than other.
Pigeonpea is a versatile crop grown primarily as a vegetable and a multi-use green crop (dhal) in India. Pigeonpea seed is composed of cotyledons (85\%), embryo (1\%) and seed coat (14\%). Fusarium wilt is the most important disease of pigeonpea in India which is responsible for yield losses up to 67 per cent at maturity and 100 per cent in case of infection at pre-pod stage (Kannaiyan and Nene, 1981). Seedborne diseases are regarded as major constraints in pigeonpea (Cajanus cajan (L.) Millsp.) production. Seedborne pathogens produce toxic metabolites, which 
adversely affect germination as well as seedling vigour. The literature revealed that more than hundred pathogens are known to affect the pigeonpea crop. Amongst them Fusarium wilt, Alternaria blight, Phytophthora blight, Alternaria leaf spot, Rhizoctonia root rot and Cercospora leaf spot are the most common fungal pathogens associated with stored seeds, mainly responsible for seed deterioration and reduction in the germination potential and also seedling vigour. Fungi of genera Aspergillus, Fusarium, Penicillium and Rhizoctonia produce toxic substances (Singh et al., 1991) that cause decrease in the quality of seeds. Fusarium wilt characterized by wilting of the affected plants and characteristic internal browning or blackening of the xylem vessels extending from root system to stems. Partial wilting of the plants and patches of dead plants were reported to be common in the fields during advanced stages of plant growth. Present investigation was carried out with in vitro evaluation of fungicides for control of Fusarium oxysporum f. sp. udum causing wilt disease of Pigeonpea.

\section{Materials and Methods}

The experiments (in vitro) were conducted at Department of Plant Pathology, College of Agriculture, Latur during 2018-2019. Efficacy of various seed dressing fungicides were evaluated at their recommended dosages against Fusarium oxysporum f. sp.udum,by applying Poisoned food technique (Nene and Thapliyal, 1993) and using Potato Dextrose Agar (PDA) as a basal culture medium. Based on active ingredient, requisite quantity of each test fungicide was calculated and mixed thoroughly with autoclaved and cooled $\left(45^{\circ} \mathrm{C}\right)$ PDA medium separately in conical flasks to obtain desired concentrations of the test fungicides. Fungicide amended PDA medium was then poured (20 $\mathrm{ml} /$ plate) separately and aseptically in Petri plates (90 $\mathrm{mm} \mathrm{dia.)}$ and allowed to solidify at room temperature. After solidification of the medium, all the plates were inoculated aseptically by putting in the center a $5 \mathrm{~mm}$ culture disc obtained from a week old actively growing pure culture of $F$. oxysporum f. sp. udum. Each of the test fungicides and its concentration was replicated three times. Test pathogens were assessed separately. Petri plates filled with plain PDA (without fungicide) and inoculated with the culture disc of $F$. oxysporum $\mathrm{f}$. sp. udum. Fungal and bacterial biocontrol agents were evaluated in-vitro against Fusarium oxysporum f. sp. Udum fungi pathogenic to pigeonpea, applying dual culture technique (Dennis and Webster, 1971). Seven days old cultures of the test bio-agents and the pathogens were used for the study. Discs of 5 mm diameter of culture growth of the $F$. oxysporum f. sp. Udum the test bioagents were cut out with sterilized cork borer. Then two culture discs, one each of the test fungus and test bio-agent were placed at equidistance and exactly opposite to each other on autoclaved and cooled PDA medium in petri plates and incubated at $26 \pm 2{ }^{\circ} \mathrm{C}$. Test pathogens were assessed separately. PDA plates inoculated separately with culture disc of $F$. oxysporum f. sp. Udum were maintained as untreated control. The colony diameter of the fungus pathogens on medium was recorded and per cent inhibition was calculated by using following formula (Vincent, 1927).

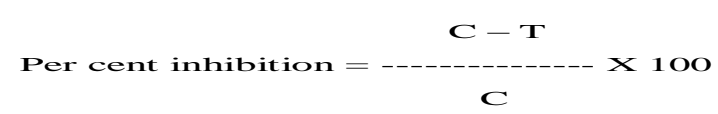

Where,

$\mathrm{C}=$ growth of the test fungus in untreated control plate

$\mathrm{T}=$ growth of the test fungus in treated plate

\section{Results and Discussion}

A total of eight seed dressing fungicides at their recommended field dosages were evaluated in vitro by Poisoned food 
technique, against Fusarium oxysporum f. sp. Udum of pigeonpea which were detected in seed health testing methods and the results obtained on their colony diameter $(\mathrm{mm})$ and per cent inhibition of mycelial growth are presented in Table 1.

Table.1 In vitro efficacy of various fungicides against $F$. oxysporum f. sp. udum associated with pigeonpea seeds

\begin{tabular}{|c|c|c|c|}
\hline \multirow[t]{2}{*}{ Sr. No. } & \multirow[t]{2}{*}{ Treatments } & \multicolumn{2}{|c|}{ F. oxysporum f. sp. udum } \\
\hline & & $\begin{array}{c}\text { Colony } \\
\text { diameter }(\mathrm{mm})\end{array}$ & $\begin{array}{c}\text { Inhibition } \\
(\%)\end{array}$ \\
\hline $\mathbf{T}_{1}$ & Carbendazim 50\% WP & 10.00 & $88.88(70.52)$ \\
\hline $\mathbf{T}_{2}$ & Thiophanate methyl $70 \%$ WP & 10.50 & $88.33(70.02)$ \\
\hline $\mathbf{T}_{3}$ & Tebuconazole $25 \% \mathrm{WP}$ & 0.00 & $100(90.00)$ \\
\hline $\mathbf{T}_{4}$ & Captan 75 WP & 17.78 & $80.24(63.60)$ \\
\hline $\mathbf{T}_{5}$ & Pyroclostrobin $20 \% \mathrm{WG}$ & 47.43 & $47.30(43.45)$ \\
\hline $\mathbf{T}_{6}$ & Carboxin $37.5 \%$ + Thiram $37.5 \% \mathrm{WP}$ & 0.00 & $100(90.00)$ \\
\hline $\mathbf{T}_{7}$ & Carbendazim $12 \%+$ Mancozeb $63 \%$ WP & 0.00 & $100(90.00)$ \\
\hline $\mathbf{T}_{8}$ & Control (untreated) & 90 & $0.00(00)$ \\
\hline & $\mathbf{S E} \pm$ & 0.39 & 0.61 \\
\hline & $\mathrm{CD}(\mathrm{P}=\mathrm{s} 0.01 \%)$ & 1.16 & 1.79 \\
\hline
\end{tabular}

Table.2 In vitro efficacy of various bioagents against F.oxysporum f. sp. Udum associated with pigeonpea seeds

\begin{tabular}{|c|c|c|c|}
\hline Sr. No. & Treatments & \multicolumn{2}{|c|}{ F.oxysporumf. sp. udum } \\
\hline & & $\begin{array}{c}\text { Colony } \\
\text { Inhibition (\%) }\end{array}$ \\
\hline $\mathbf{T}_{\mathbf{1}}$ & T. asperellum & 20.41 & $77.32(61.56)$ \\
\hline $\mathbf{T}_{\mathbf{2}}$ & T. harzianum & 12.94 & $85.62(67.71)$ \\
\hline $\mathbf{T}_{\mathbf{3}}$ & T. hamatum & 15.65 & $82.61(65.35)$ \\
\hline $\mathbf{T}_{\mathbf{4}}$ & T. koningii & 24.50 & $72.77(58.54)$ \\
\hline $\mathbf{T}_{\mathbf{5}}$ & T. longibrachitum & 34.52 & $61.64(51.73)$ \\
\hline $\mathbf{T}_{\mathbf{6}}$ & Aspergillusniger & 21.95 & $75.61(60.40)$ \\
\hline $\mathbf{T}_{\mathbf{7}}$ & Pseudomonas fluorescens & 47.80 & $46.88(43.21)$ \\
\hline $\mathbf{T}_{\mathbf{8}}$ & Control (Untreated) & 90.00 & $0.00(00)$ \\
\hline & SE \pm & $\mathbf{0 . 8 9}$ & $\mathbf{0 . 8 0}$ \\
\hline & CD (P=s0.01\%) & $\mathbf{2 . 6 1}$ & $\mathbf{2 . 3 6}$ \\
\hline
\end{tabular}

The results revealed that, all of the test fungicides exhbited significant mycelial growth inhibition of the Fusarium oxysporum f. sp. udum over untreated control. However, the fungicides viz., tebuconazole 25\% WG @ $0.2 \%$, carboxin $37.5 \%$ + thiram $37.5 \%$ 75WP (a) $0.25 \%$ and carbendazim $12 \%+$ mancozeb
63\% 75WP @ 0.25\% resulted in 100 per cent inhibition of mycelial growth of Fusarium oxysporum f. sp. udum. Rest of the fungicides, which also caused significant mycelial growth inhibition of Fusarium oxysporum f. sp. udum were carbendazim 50\% WP @ $0.1 \%$ (88.88\%), thiophanate methyl 70\% WP @ 
$0.1 \%(88.33 \%)$, followed by captan $75 \% \mathrm{WP}$ @ $0.3 \%(80.24 \%)$ and pyroclostrobin 20\% WG @ 0.1\% (47.30\%). Thus, except the fungicide pyroclostrobin $20 \% \mathrm{WG}$ at their recommended dosage, rest of the six seed dressing fungicides tested were found highly effective against Fusarium oxysporum f. sp. udum.

A total of seven bioagents were evaluated in vitro by dual culture technique, against Fusarium oxysporum f. sp. Udum of pigeonpea and the results obtained on colony diameter $(\mathrm{mm})$ and per cent inhibition of mycelial growth of these test fungi are presented in (Table 2). For (Table 2) Fusarium oxysporum f. sp. Udum significantly highest mycelial growth inhibition was with $T$. harzianum $(85.62 \%)$, followed by $T$. hamatum $(82.61 \%), T$. asperellum (77.32\%), A. niger (75.61\%), T. koningii $(72.77 \%) \quad$ T. longibrachatum $(61.64 \%)$ and P. fluorescens $(46.88 \%)$.

Therefore, in present study, various Trichoderma spp., followed by A. niger and $P$. fluorescens were also found effective against seedborne pathogenic fungi of pigeonpea and also reported as most effective against pigeonpea seed borne diseases by several earlier workers (Dhar et al., 2006, Gadeet al., 2007; Lokesha and Benagi, 2007; Barde et al., 2016; Athira, 2017; Devamani et al., 2017 and Kadam et al., 2018).

\section{References}

Athira, K. (2017). Efficacy of fungicide and bio-control agents against root rot of blackgram (Vigna mungo L.) caused by Macrophomina phaseolina(Tassi) goid. Int. J. Curr. Microbiol App. Sci. 6(10): 2601-2607.

Barde P. S., Gupta V. R., Giri G. K. and Mane S. S. (2016). Antagonistic efficiency of native Trichoderma and
Penicillium against soilborne pathogens of pigeonpea and their compatibility. $J$. Pl. Dis. Sci. 11 (2): 183-188.

Chaudhary Dinesh H, Pathak D.M. and Chaudhary Mahesh M. (2017 ). In vitro efficacy of fungicides against dry root rot (Macrophomina phaseolina) of Soybean. Int. J. Curr. Microbiol. App. Sci. 6(8): 1298-1301.

Devamani, B.D. Saifulla, M. and Jayappa (2017). Efficacy of fungicides and bioagents on seed mycoflora of mung bean (Vigna radiata L.). Int. J. Pure App.Biosci.5(3): 231-237.

DharVishwa, Mishra, S. and Chaudhari, R.G. (2006). Different efficacy of bioagents against Fusarium udum isolates. Indian Phytopath. 59(3): 290-293.

Gade R.M., Zote K.K., and Mayee C.D. (2007). Integrated management of pigeonpea wilt using fungicide and bioagent. Indian phytopath. 60 (1): 2430.

Kadam V. A., Dhutraj D. N., Pawar D. V. and Patil D. D. (2018). Bio efficacy ofbioagents and botanicals against Alternaria alternate (Fr.) keisslerc ausing leaf spot of pomegranate. Int. J. Curr. Microbiol. App. Sci. 7(11):11461155.

Kannaiyan, J. Nene, Y. L. and Sheila, V. K. (1980). Control of mycoflora associated with pigeonpea seeds. Indian J. Pl. Prot. 8(2): 93-98.

Lokesha N. M. and Benagi V. I. (2007). Biologically management of pigeonpea dry root rot caused by Macrophomina phaseolina. Karnataka J. Agric. Sci.,20(1): 54-56.

Nene, Y.L. and Thapliyal, R.N. (1993). Fungicides in plant disease control third edition. IBH Pub. Co. New Delhi. P. 33.

Pandey, V. Kumar, N. and Tripathi, N.N. (2007). Inhibition of fungal deterioration of stored pigeonpea seeds by Cuminum cyminum oil. Indian 
Phytopath, 60(3): 306-312.

Sheela Shinde (2013). Isolation of seedborne fungi associated with pigeonpea (Cajanus cajan (L.) Mill sp.) Seeds. Int. J. Sci. Res., 5: 2319-7064.

Singh, K. J. Frisvad, C. Thrane, U. and Mathur, S. B. (1991).An illustrated manual on identification of some seedborne Aspergillus, Fusarium, Penicillia and their mycotoxins. AiOTryk as Odense, Denmark, pp: 133. Vincent, J.M. (1927). Distoration of fungal hyphae in presence of certain inhibitors. Nature. 59: 850.

\section{How to cite this article:}

Pradnya Khillare, Sunita J. Magar and Markad, H. N. 2020. In vitro Efficacy of Fungicides and Bioagents against Wilt of Pigeonpea Caused by Fusarium oxysporum f. sp. udum. Int.J.Curr.Microbiol.App.Sci. 9(09): 1938-1942. doi: https://doi.org/10.20546/ijcmas.2020.909.243 